\title{
SYNERGISING INTERNATIONAL LABOUR LAWS AND HUMAN RIGHTS FOR PROTECTION OF INDONESIAN MIGRANT WORKERS
}

\author{
Muhammad Abdul Azis ${ }^{1}$, M. Syaprin Zahidi², David Pradhan ${ }^{3}$ \\ ${ }^{1}$ International Relations Department, Faculty of Social and Political Sciences, \\ Universitas Muhammadiyah Malang, Indonesia, Email: maaazis0150@gmail.com \\ ${ }^{2}$ International Relations Department, Faculty of Social and Political Sciences, \\ Universitas Muhammadiyah Malang, Indonesia Email: syaprin123@umm.ac.id \\ ${ }^{3}$ School of International Studies, Jawaharlal Nehru University, India, Email: \\ happy48_isa@jnu.ac.in
}

Submitted: July 13, 2020; Reviewed: August 18, 2020; Accepted: September 3, 2020

\begin{tabular}{ll}
\hline \multicolumn{1}{c}{ Article Info } & \multicolumn{1}{c}{ Abstract } \\
\hline Keywords: & Efforts in promoting international legal protection of \\
TKI, Protection, Human, & Indonesian migrant workers can be explained that it has \\
Rights. & complete regulations. This situation cannot be separated \\
& from the facts that show the importance of granting Specific \\
DOI: & labour rights for migrant workers in the international \\
10.25041/lajil.v2i2.2036 & community's perspective. The purposes of this article are to \\
& encourage all people to consider seriously the applying of \\
& international human rights law in order to promote of human \\
& rights, especially, for Indonesia migrant workers (TKI) and \\
& create better migration management. In legal-formal matter, \\
& the applying of legal mechanisms has been recognized as \\
& human rights by Indonesia law. One of the best ways is \\
& trying to join the outside world in order to attain Economic \\
& development for the nation. Exploiting Opportunities of \\
& globalized world economy does not mean our sovereignty \\
& weakened but rather as an effort to achieve more substantive \\
& effort. This can be interpreted as a political commitment \\
from the government - by learning and cooperating with & Other States - to be more pragmatic by prioritizing the \\
interests of the people as a form of democracy.
\end{tabular}

\section{A. Introduction}

In ASEAN, especially in Malaysia, start to abandon the principle of non-intervention to the issue of Human Rights in Myanmar. ${ }^{1}$ From that case, consideration of International human rights deserves to occupy a central place in the policy-making process, either that is domestic or foreign. It cannot separate from human nature itself that has implications to all aspects of life, from individual behaviour affect other persons to a country that get a relation to its

\footnotetext{
${ }^{1}$ Wayne Arnold, International Herald Tribune, 3
} 
people. ${ }^{2}$ For example, in the previous issue of sexual orientation, it is viewed traditionally merely morality, but in this current time, it cannot be separated from the issue of the individual right of a person. ${ }^{3}$ Similarly, in the level of the international community, it assumes the law has not powered of binding when we transgress jus cogens that are human values which have been recognized by the international community. ${ }^{4}$

At the practical level of international law about recognition of the countries and government at this time has encountered a fundamental change to the inclusion of respect to human rights as a precondition for giving the recognition. ${ }^{5}$ In fact, European Union member states that future candidates that want to get in the European Union must have Constitutionalisation of rights. ${ }^{6}$ Human rights in Indonesia have been strictly regulated in the 1945 Indonesian Constitution. ${ }^{7}$ Thus, in practical condition utility of human rights law is necessary to all policy-making process in all sectors in both national and international levels.

In addition, with increasing awareness of human rights discourse ${ }^{8}$ and many practices of democratization in all parts of the world -whether carried out under pressure or voluntarilyhas added justification for utilization of international law itself in the domestic level as a tool for strengthening democratic system in National level. ${ }^{9}$ It is not surprising that international law can be used as a tool for promoting developing countries' interest, though. ${ }^{10}$ From that fact, scepticism over the universality of international law as the law of all nations in this recent time had become relevant. ${ }^{11}$ Same as with sociological-anthropological debate between relativists and universalist related to the validity of human rights become irrelevant. ${ }^{12}$

In the context of promoting international legal protection of Indonesian migrant, workers can be explained that it has complete regulations. ${ }^{13}$ This situation cannot be separated from the facts that show the importance of granting specific rights for migrant workers in the

\footnotetext{
2 Jack Donnelly, Universal Human Rights in Theory and Practice (Ithaca: Cornell University Press, 2003). For the critic, look Hilary Charlesworth, "What are 'Women's International Human Rights?," In Rebecca Cook (ed.), Women's Rights in International Law, (Philadelphia: University of Pennsylvania Press, 1994), 54-58.

${ }^{3}$ Law in case Lawrence v. Texas, 123 S.Ct. 2472 (2003)

${ }^{4}$ Article 53 of Vienna Convention on the Law of Treaties states that a treaty will be void if "it is incompatible with peremptory norms of the general international law"

${ }^{5}$ Eric Stein, "INTERNATIONAL LAW AND INTERNAL LAW: TOWARD INTERNATIONALISATION OF CENTRAL-EASTERN EUROPEAN CONSTITUTIONS," American Journal of International Law 88, no. 3 (1994): 427-450, 427, DOI: 10.2307/2203712.

${ }^{6}$ Philip Alston \& J.H.H. Weiler, "AN 'EVER CLOSER UNION' IN NEED OF A HUMAN RIGHTS POLICY”, European Journal of International Law 9, no. 2 (1998): 658-723, 658, DOI: 10.1093/ejil/9.4.658.

${ }^{7}$ Erika Norliza'Aini, Erina Pane, and Lintje Anna Marpaung, "ANALISIS PENYELESAIAN SENGKETA PARTAI SOLIDARITAS INDONESIA STUDI PUTUSAN BADAN PENGAWAS PEMILU KOTA BANDAR LAMPUNG NOMOR: 01.PS.REG.BWSL.BDL.08.01.VII.2018.," Cepalo 3, no. 2 (2019): 71-76, 73, DOI: 10.25041/cepalo.v3no2.1846.

${ }^{8}$ Regarding the concept of "Right Talk" See Ann Glendon, Right Talk: The Impoverishment of Political Discourse (New York: Free Press, 1991), 23.

9 Eyal Benvenisti, "RECLAIMING DEMOCRACY: STRATEGIC USES OF FOREIGN AND INTERNATIONAL LAW BY NATIONAL COURTS," American Journal of International Law 102, no. 2 (2008): 241-274, 241, DOI: $10.2307 / 30034538$.

${ }^{10}$ Beth Lyon, "DISCOURSE IN DEVELOPMENT: A POST-COLONIAL 'AGENDA' FOR THE UNITED NATIONS COMMITTEE ON ECONOMIC, SOCIAL, AND CULTURAL COMMITTEE," American University Journal of Gender Social Policy and Law 10, (2003): 535, DOI: 10.2139/ssrn.449301.

11 Bruno Simma, "UNIVERSALITY OF INTERNATIONAL LAW FROM THE PERSPECTIVE OF PRACTITIONER," European Journal of International Law 20, no. 2 (2009): 265-297, 265, DOI: 10.1093/ejil/chp028.

12 Philip Alston, "A Framework for the Comparative Analysis of Bills of Rights," in Philip Alstons (ed.), Promoting Human Rights through Bill of Rights: Comparative Perspective (New York: Oxford University Press, 1999), 1-3.

${ }^{13}$ Richard Plender (ed), Basic Documents on International Migration Law (Leiden and Boston: Martinus Nijhoff, 2007), 31.
} 
international community's perspective. According to this issue, Antoine Pecoud and Paul de Guchteneire see existing stagnation due to the absence of will pure because of politic itself. ${ }^{14}$ Therefore, it is appropriate if we intend to advance the law protection for migrant workers, we have to start to consider the implications of international law and apply it through the prism of human rights for the protection of the Indonesian Migrant Workers. Advancing migration management is not only good for migrant workers' human rights itself but also affects economic development, particularly, for Indonesia citizen itself. Migration is an old issue, but it still will be one of the main topics in this period and next period. In other words, migration is a reality that cannot be avoided. In fact, we have to give more efforts to manage it as well as possible for the benefits of all. It is therefore unavoidable that migration will happen and therefore this is an issue that can not be avoided.

This article purposes of encouraging all people to consider seriously the applying of international human rights law for the promotion of promoting of human rights, especially, for Indonesia migrant workers (TKI) and create better migration management. In both national and international law, the application of legal mechanisms has been recognized as human rights by Indonesia law. ${ }^{15}$ In other words, the neglecting of the application of international labour rights as embodied in International Law can be equated with human right violation.

\section{B. Discussion}

This article is based on secondary sources and relies on existing data and reports of Government and Non-Government Organisations to analyse the issue. The article is metaanalytic and utilizes the case of TKI as a heuristic for proposing the reinterpretation of international labour norms through the human rights paradigm. It is divided into four parts, each of it contains arguments that support the conclusion and suggestion that is presented. The first part contains an introduction that is mapping the issues is identified by the writer $(1 \& 2$. In the second part, it is aimed review of the Indonesia practice in its efforts of protection of human rights protection for Indonesia migrant workers (TKI) (3\&4).

\section{Review of Policy and Practices on Migrant Workers Protection}

In overall, efforts that are undertaken by the Indonesian government to protect the migrant workers might be still ad hoc (tambal-sulam). ${ }^{16}$ For instance, reactionary-emotional government attitude can be clearly seen, such as related to the termination of sending workers to Malaysia because of many human right violations. ${ }^{17}$ This is showed by confusion and rejection of the emotional reaction of the government. ${ }^{18}$ Because of this effectiveness in this such pressure, that will be counterproductive to the policy because it actually produces in increasing illegal migrant workers in Malaysia. Next, this policy can bring high human rights violation against migrant workers as a result of their migratory status. ${ }^{19}$ This termination is

14 Antoine Pécoud dan Paul deGuchteniere, "MIGRATION, HUMAN RIGHTS AND THE UNITED NATIONS: AN INVESTIGATION INTO THE OBSTACLES TO THE UN CONVENTION ON MIGRANT WORKERS' RIGHT," Windsor Yearbook of Retrievedto Justice 24, (2006): 241-244.

${ }^{15}$ Article 7 (1) of Law no. 39 of 1999 on Human Rights (hereinafter: the Human Rights Act) which states "each person has the right to use all efforts in international forums against all violations of human rights are guaranteed by international law "

${ }^{16}$ Manolo Abella dan Geoffrey Ducanes, "The Effect of the Global Economic Crisis on Asian Migrant Workers and Governments'

${ }^{17}$ Human Rights Watch, Help Wanted: Abuses against Female Migrant Domestic Workers in Indonesia and Malaysia, July 21, 2004, 31.

${ }^{18}$ http://www.pikiran-rakyat.com/index.php?mib=news.detail\&id=84352, Accessed on May 03, 2019.

${ }^{19}$ Sarah Cleveland, "LEGAL STATUS AND RIGHTS OF THE UNDOCUMENTED WORKERS," American Journal of International Law 99, no. 2 (2005): 460-465, 460, DOI: 10.2307/1562510. Beth Lyon, "New International Human Rights Standard on Unauthorized Immigrant Worker Rights: Seizing an Opportunity to Pull Government Out of Shadows," in Anne Bayefsky (ed.), Human Rights and Refugee, Internally Displaced 
intended to be pressure for Malaysia and make them revise Memorandum of Understanding (MoU) that previously they had agreed with. This MoU between the Government of Indonesia and Malaysia governs the Private contractual agreement that employers enter into with the TKI. Though a subject of Private International Contract, the involvement of the Sovereign States in the framing and negotiating the regulations of these Private contractual agreements, and possibly even taking over cases in which the citizens of Indonesia are adversely affected through Subrogation as parens patriae does bring it within the ambit of International Law especially since the protection of the rights of its citizens, even when they are outside the State is a duty of the Government. ${ }^{20}$ Due to the extreme diversity in the provisions of the private contractual agreements encountered, this article focuses on the macro-legal aspect of State duty under International Law to protect its citizens from violations of their rights when they are employed outside its territorial jurisdiction and suggests the deployment of a human rights approach as a universal normative imperative to achieve it more effectively. ${ }^{21}$

The purpose of revised MoU itself is to remove the provision which authorizes household to hold documents of Indonesian migrant workers. ${ }^{22}$ If we get attention to the actual issue, in particular, it can be avoided when the planner of MoU, especially from Indonesia, understand the principles of international legal migration. ${ }^{23}$ One of the functions of CMW ratification is to provide the understanding to the relevant officials regarding good practices in terms of immigration. In popular practice, the employer holds identity documents has seen as an obligation for the recipient country to ensure compliance with the national laws related to immigration is conducted. Thus, publishing of these provisions is a faux pas which affects the labour rights of the TKI and creates disproportionate power of the foreign employer over the TKI. In the next section, a review is done, of the extent towards how far Recourse to the utilization of international legal regimes (for protection of citizens under private international contract) by the Government of Indonesia.

\section{Utilizing of International Law by Indonesia Government}

Existing secondary literature and data regarding the utilizing of International law by the Indonesia government in its efforts to protect migrant workers can still be seen far from satisfactory. Indonesia government actions clearly demonstrate this situation merely signed a cooperation agreement with recipient state to migrant workers (host state), namely Malaysia in 2004 and Jordan and Kuwait in 1999. ${ }^{24}$ This article focuses on these countries as a majority of labour disputes relating to a violation of Private contract of International employment are reported from these countries. To be fair, Indonesia has also drawn up agreements with other States to protect the rights of the TKI, but they are not being considered here for the sake of focussing on the topic.

The exaggerated expectation of this $\mathrm{MoU}$ is misplaced because $\mathrm{MoU}$ is not an international agreement, treaty or convention that is contemplated by Article 2 (1) Vienna

Persons and Migrant Workers (Netherlands: Koninklijke Brill, 2005): 554-66; Laurie Berg, “At the Broder and between the Cracks: The Precarious Position of Irregular Migrant Workers under International Human Rights Law," Melbourne Journal of International Law 8, no. 1 (2007): 287-320, https://doi.org/10.4324/9781315248967-12.

20 Archibugi, D. and Held, D., Cosmopolitan democracy. An agenda for a New World Order (Cambridge: Polity Press, 1995), 21.

21 R. Bauböck, "Citizenship: International, State, Migrant and Democratic Perspectives". In Globalizing Migration Regimes, (Avebury: Ashgate, 2006), 144-166.

${ }^{22}$ http://www.nakertrans.go.id/news.html,253, Accessed on May 3, 2019.

${ }^{23}$ Migration in an Interconnected World: New Direction for Actions.

${ }^{24}$ Tribun Jabar, edition Monday, 19/11/2007. 
Convention $1969 .{ }^{25} \mathrm{MoU}$ is more appropriate as a commitment that makes the breaching party is hard to ask a responsibility. This is shown by using of ambiguous terms such as "will" rather than "shall" which is common in the legal documents. Generally, MoU is intended to set regulations on issues such as the confidential defence of the country. ${ }^{26}$ Excessive attention to MoU results in inefficiency if we consider that the number of the host country will continue to increase over time. For example, Indonesia until now cannot make MoU with Saudi Arabia, which is a destination country that is many Indonesia migrant workers Migrate to for employment. ${ }^{27}$ Participation of Indonesia in multilateral treaties that is related to the promotion of the interests of migrant workers can be said far from satisfactory. Until now, Indonesia has successfully ratified convention that is classified by the International Labour Organization (ILO) as a basic instrument. ${ }^{28}$ However, Indonesia does not sign any ILO conventions that are specifically intended to migrant workers yet. ${ }^{29}$ Likewise, signatory against CMW itself, Indonesia has not signed it. It further shows Indonesia does not seem real to look for international law as relevancy for the protection of migrant workers.

Similarly, it can be seen in the optimization of ASEAN's role in this case. ${ }^{30}$ Instead, ASEAN in designing its charter tends to be busy with its acquisition status law which is already not a problem anymore. But, what we need to concern is what ASEAN can do for the citizens of its member states. Until now, ASEAN is only capable of publishing the ASEAN Declaration for promoting and protecting the human right of migrant workers on January 13, 2007, in Cebu, Philippines, which does not have binding force. ${ }^{31}$

Similarly, the establishment of a regional human rights mechanism is still a mere expectation. One of them is the establishment of the Human Rights Commission that is composed of representatives of the government. After that, the commission also only has a role as a consultative organ just for member states. In addition, the commission is not given the authority of receiving complaints. In fact, in the Commission's Terms of Reference (ToR) has the commission's objectives that not only promote but also engaged in the protection sector. ${ }^{32}$ Focusing on promotion aspects, according to Sihasak Phuangketkeow, Chairman of the high s a planner of the ToR, Terms of Reference can be separated from realistic attitude. ${ }^{33}$ This situation shows that Indonesia leadership in ASEAN has diminished Whereas, in ASEAN, besides Indonesia, there are Philippines and Vietnam that are also countries that are sending many migrant workers in the world.

Meanwhile, from statement on its official website, BNP2TKI explained various achievement that they had done. ${ }^{34}$ Two examples that to be noted here are: (i) signing MoU with ILO on May 302007 in order to streamline and utilizing ILO's helps in Capacity Building sector and training for staffs BNP2TKI; (ii) Exploring the cooperation network with

\footnotetext{
${ }^{25}$ Contents this article "'treaty' means an international agreement concluded between States in written form and governed by international law, whether embodied in a single instrument or in two or more related instruments and whatever its particular designation",

${ }^{26}$ Anthony Aust, Handbook of International Law (New York: Cambridge University Press, 2005), 7-55.

${ }^{27}$ KOMPAS.com, TKI Tewas Dianiaya Majikan di Arab Saudi, Accessed on May 3, 2019.

28 List ILO instruments that has ratified by Indonesia can be found in http://www.ilo.org/ilolex/english/newratframeE.htm, Accessed on May 3, 2019.

${ }^{29} \mathrm{http}: / /$ www.ilo.org/ilolex/english/newratframeE.htm, Accessed on May 3, 2019.

${ }^{30}$ Ceah Whui Ling, "MIGRANT WORKERS AS CITIZENS WITHIN THE ASEAN LANDSCAPE: INTERNATIONAL LAW AND THE SINGAPORE EXPERIMENT," Chinese Journal of International Law 8, no. 1 (2009): 205-231, 205, DOI: 10.1093/chinesejil/jmn041.

${ }^{31} \mathrm{http}: / /$ www.12thaseansummit.org.ph/innertemplate3.asp?category=docs\&docid=23, Accessed on May 3, 2019.

${ }^{32}$ Look Terms of Reference of ASEAN Intergovermental Commission of Human Rights, adopted from ministerial session on 19-20 July 2009 can be found on: http://www.asean.org/DOC-TOR-AHRB.pdf, Accessed on May 3, 2019.

${ }^{33} \mathrm{http}: / /$ www.aseansec.org/HLP-OtherDoc-1.pdf, Accessed on May 3, 2019.

${ }^{34} \mathrm{http}: / /$ bnp2tki.go.id/content/view/226/85/, Accessed on May 3, 2019.
} 
a various international institution such as USIS, ASEAN, ECOSOC, AANZ (ASEAN, Australia, and New Zealand), GFMD (Global Forum on Migration and Development), ACILS (American Center for International Labor Solidarity), IOM (International Organization for Migration), WTO (World Trade Organization), and UNIFEM (United Nations Development Funds for Migration), that is intended as an effort to strengthen Indonesia bargaining position in protecting migrant workers in the placement countries. Unfortunately, various forms of that cooperation are hard to know by the public, in particular, regarding concrete benefits that they produce. Nicola Piper and Robyn Iredale, in their study, examine obstacle in the ratification of CMW, as follows; ${ }^{35}$

Indonesia has a weakness in governance structures and bureaucratic problems that make Indonesia does not have a strategic policy that focuses on long-term development. ${ }^{36}$ Additionally, it is related to policies that are connected to the issue of immigration that only becomes an issue in ministerial level and the worst thing is a major consideration of planning the policy formation more emphasis on efforts to reduce unemployment rather than questioning the establishment of expensive protection mechanisms. ${ }^{37}$ Circumstances are exacerbated by the emphasis on policy for creating political stability and national integration.

Another reason that is an underlying refusal of the government to ratify CWM cannot be divided from a belief that is in the decline of interest in countries that have been receiving Indonesia migrant workers. In addition, they do not want to open confrontation with that recipient countries. CMW, in their perception, is seen to be not necessary to get action because that recipient countries is not their state members. Because of it, if we ratify CMW, it is just left benefit for foreign workers that work in Indonesia. Generally, they have better condition than Indonesia migrant workers. Another reason is related to confidence of loss of livelihood as a result of the exposure that is forced by CMW. Absence of pressure has become a driving force for CWM waiver.

The last is limited human resources and finance for funding the complex processes, such as obligations to providing a report. ${ }^{38}$ This situation is upside down with the Philippines and Mexico that are very active to employ International law for promoting the rights of their migrant workers. Philippine is not only active in International law but also consistently apply at the domestic level. As for its proactive policy, along with Mexico, become countries that are succeeding in making issue migrant workers' rights as part of the International community agenda. ${ }^{39}$ One of its phenomenal achievements is the birth of Advisory Opinion number 18 related to strengthening the application of the non-discrimination principle against migrant workers who do not a valid immigration document. ${ }^{40}$ In that decision, the Inter-America court insists the principle of non-discrimination must be treated to all people without looking at their immigration status. ${ }^{41}$ Related with that, Sarah Cleveland considers that decision that has been discussed in detail, so it can provide important contribute associated with the development of undocumented migrant workers in America and other places in the world. ${ }^{42}$

\section{Efforts in Foreign Country}

\footnotetext{
${ }^{35}$ Nicola Piper and Robyn Iredale, "Identification of the Obstacles to the Signing and Ratification of the UN Convention on the Protection of the Rights of All Migrant Workers: The Asia Pacific Perspective," UNESCO Series of Country Reports on the Ratification of the UN Convention on Migrants UNESCO (2003).

${ }^{36}$ Ibid., 4-23

${ }^{37}$ Ibid., 21.

${ }^{38}$ Ibid., 5-23.

${ }^{39}$ Beth Lyon, Loc.Cit.

${ }^{40} \mathrm{http} / / / \mathrm{www}$. corteidh.or.cr/seriea_ing/index.html, Accessed on May 3, 2019.

${ }^{41} \mathrm{http} / / /$ www.cidh.org/annualrep/2002eng/chap.6.htm\#I.\%20\%20\%20\%20\%20\%20\%20\%20INTRODUCTION, Accessed on May 3, 2019.

${ }^{42}$ Sarah Cleveland, Op. Cit., 460
} 
Migrants are one of a group that is very vulnerable to all forms of Human Rights abuse in a foreign country. This situation cannot be separated from a negative view of migrants themselves. ${ }^{43}$ This is clearly shown by a survey that is conducted by Pew Global Research on perspectives of the world community towards immigrants. ${ }^{44}$ This perspective can be unconnected from the belief that migrants lead to increasing spending public and low salaries for the local community ${ }^{45}$. Here we review steps that have been done by the Indonesia government in the recipient countries.

For protecting migrant workers, the government has taken the following steps; (i) minister issued decree no. 157/MEN/2003 on Protection Insurance for Indonesia migrant workers overseas; (ii) providing guidance for migrant workers in some countries (Saudi Arabia, Kuwait, and Malaysia) by advocacy team that is composed students and civil servants that are working in the related country and local attorneys from that country. This team must record, monitor, and defend migrant workers in a foreign country.

First policy related to a procurement insurance program for migrant workers does not have a clear positive effect. Not less, Jumhur Hidayat as Chair of Board Placement and Protection of Indonesia Migrant Workers (BNP2TKI) states that all consortiums that are existed are "shoddy". ${ }^{46}$ It can be that money 400.000 IDR become new corruption area. It connects to Indonesia migrant workers do not want to get along with that problem. ${ }^{47}$ Interestingly, Jumhur instead will force the migrant workers to pay the insurance in the future. ${ }^{48}$ Even more ridiculous is the desire of Minister of Manpower, Erman Shepard, recently wanted to form a new consortium which holds monopoly that he considers it can resolve the problem that had been haunting him. Rather than solving that problem, it causes a confrontation with Business Competition Supervisory (KPPU) because it may violate act no. 51999 of Anti-Monopoly. ${ }^{49}$

The second policy that is most attractive policy-establishing is cooperation with local parties and forms advocacy team that is composed of local lawyers, students, and civil servants. This policy also cannot be felt significantly by Indonesia migrant workers. Research indicates that most of the TKI is not aware of the existence of this initiative in the country that they work in. A common institution such as Retrievedto the embassy, according to Indonesia migrant workers, is suggested to become more complicated.

For example, in countries of East Asia such as Hong Kong and South Korea that become the main destination for Indonesia migrant workers, is classified as a democratic country, so that, presence and role of civil community is strong enough. In countries like that, migrant workers are likely to get help from the International Non-Governmental Organization (INGO), which is referred to as "shelter" for Indonesia migrant workers. ${ }^{50}$ Therefore, it is appropriate if a study is aimed at improving the ability of workers, Filipino migrants recommend programs such as education and organization that has a purpose at improving

\footnotetext{
${ }^{43}$ Jorge Bustamante, "Immigrant Vulnerabilities, Loc.Cit.

${ }^{44}$ Pew Research Centre, World Publics Welcome Global Trade - But Not Immigration: 47-Nation Pew Global Attitudes Project, October 4, 2007.

45 Gordon H. Hanson, The Economic Logic of Illegal Immigration (New York: Council on Foreign Relations, 2007), 19-21.

${ }^{46} \mathrm{http} / / / \mathrm{www} \cdot$ antara.co.id/view/?i=1199882713\&c=NAS\&s=, Accessed on May 3, 2019.

$47 \mathrm{http}: / /$ www.tempointeraktif.com/hg/nasional/2006/10/01/brk,20061001-85125,id.html, Accessed on May 3, 2019.

${ }^{48}$ Kantor Berita Antara, Jumhur: Semua Asuransi, Loc.Cit.

${ }^{49} \mathrm{http}: / /$ www.majalahtrust.com/ekonomi/ keuangan/981.php, Accessed on May 3, 2019.

${ }^{50} \mathrm{http}: / /$ www.amnestyusa.org/ document.php?id=engasa250072006\&lang=e, Accessed on May 3, 2019.
} 
awareness of labour rights and its human rights respectively. ${ }^{51}$ Correspondingly, law for Filipino migrant workers is clearly based on the recognition of the important role of NGOs in the struggle for human rights and welfare of migrant workers. ${ }^{52}$

That situation is very different from destination countries in Middle East Asia, generally, still, adhere to Monarchy absolute systems such as Saudi Arabia or Bahrain where existence and position of civil society are very weak. ${ }^{53}$ In fact, Bahrain has occurred criminalization of domestic migrant workers by local law enforcement, in this case, police. ${ }^{54}$ In such countries, the role of the embassy and local law enforcement agencies are really vital.

As a consequence, in the future, designing a system of legal protection For the labour rights (under Private International Law in a foreign country must include the specific need for the Government of Indonesia to use International Law principles for ensuring that its citizens are not left helpless and prone to exploitation, which in the absence of specific bilateral or multilateral Treaties can be done by resorting to the universal Human Rights as a means of ensuring compliance with international labour law norms. These considerations are extremely important because the deployment of migrant workers are not only limited in certain countries or region but it has widespread. Moreover, in the future, BNP2TKI will send Indonesia migrant workers to Australia in a sizeable numbers. ${ }^{55}$

In connection with that, it needs to mention the approach that is initiated by Professor Jennifer Gordon, a prominent migrants' human rights, which is based on transnational political citizenship theory. This proposal cannot be separated from disbelief on the effectiveness of traditional methods that emphasize on tightening the border as a result of the increased market demand at the global level. As a consequence, he proposed a merger between civic workers with citizenship against a country. This is evidenced by the emphasis on the importance of local labour organization so it must get more attention since they can receive membership of migrant workers ${ }^{56}$. In addition, a more significantly important feature in this proposal is to Utilize the rights discourse as an enabling instrument for the achievement of policy goals. In other words, Retrieved of migrants to maintain or defend its own interest, either in the recipient country or origin will become the main focus. This approach is intended to be able to move profits from "pander" to the migrant workers. ${ }^{57}$

\section{Efforts in Domestic Level}

His urging can show the dissatisfaction of President as the top management executive in Indonesia on the issue of migrant workers for the formation of "early warning system" that is expected to respond all Indonesia migrant workers' problem faster. ${ }^{58}$ In other words, this pressure should be seen as confirmation of dissatisfaction on a system that has been existed. One of the problems on the protection of migrant workers that exists today can be said not in overlap authority which will lead to complexity. This overlap seems increasing over time. It considers there any possibility that each Manpower and Transmigration Office in each district will have a task force team (SATGAS) such as policeman that is guarding against making

\footnotetext{
${ }^{51}$ Rene E. Ofreneo dan Isabelo A. Samonte, "EMPOWERING FILIPINO MIGRANT WORKERS: POLICY ISSUES AND CHALLENGES," International Migration Papers, no. 62, Jenewa: International Labor Office, (2004).

${ }^{52}$ Rene E. Ofreneo dan Isabelo A. Samonte, Op. Cit., 3

${ }^{53}$ The economist title Waking from Its Sleep in edition July 25-31, 2009.

${ }^{54}$ Staci Strobl, Loc.Cit.

${ }^{55}$ http://bnp2tki.go.id/ content/view/1394/231/, Loc.Cit.

56 Jennifer Gordon, "TRANSNATIONAL NATIONAL LABOR CITIZENSHIP," Southern California Law Review 80, (2007): 503.

${ }^{57}$ http://www.law.berkeley.edu/files/Gordon_Transnatl_Labor_Final.pdf, Accessed on May 3, 2019.

${ }^{58} \mathrm{http}: / / w w w . d e p k o m i n f o . g o . i d / 2009 / 06 / 11 /$ presiden-bentuk-sistem-deteksi-dini-perlindungan-tki/, Accessed on May 3, 2019.
} 
Indonesia migrant workers can go to a foreign country. ${ }^{59}$ Because of irregularities construction of protection system for Indonesia migrant workers, it starts with BNP2TKI formation itself.

Instead of protecting, this regulation even is a scary monster that is increasingly encouraging Indonesia migrant workers to abstain. In addition, the paternalistic approach that has been adopted towards Indonesian migrant workers are not only detrimental for Indonesia migrant workers economically, but also it has claimed their dignity as human beings. Furthermore, this situation has been pushing to create side effects that are quite serious such as, sexual harassment, violence, extortion, heist, and fraud. In short, the right proverb that can describe this relationship with Indonesia migrant workers is "backstabber". In the beginning, BNP2TKI initially intended to be a coordinating institution between agencies or related department. Still, in progress, the institution is more active a role in the governing institution for the employment of Indonesia migrant workers. ${ }^{60}$

Moreover, BNP2TKI has to get conflict with the Department of Manpower and Transmigration. In addition, common understanding of the notion of migrant workers also vary, the Ministry of Social Affairs is covering the Indonesia migrant workers who work outside home areas that are still under the jurisdiction of Indonesia government. ${ }^{61}$ It has been confirmed by Businessman's Association Migrant Workers Placement Service (Himsataki) which requested that the Ministry of Manpower, BNP2TKI, and Department of Foreign Affairs cooperate. ${ }^{62}$ From that statement, we can conclude that the first issue is the issue of inter-agency coordination, and obviously, it is not resolved by the presence of BNP2TKI. Maze of authority has resulted in the implementation of ministerial coordination meeting for Indonesia migrant workers that are problematic and conduct:

Decree of Coordinating Minister of People's Welfare No. 09/KEP/MENKO/Welfare/ III / 2008 dated March 6, 2008, established the Coordinating Team for the Return Policy Formulation Indonesian Manpower Problems and Their Families from Malaysia (FK-PTKIB TK), which given the task within 30 days to: (1) coordinate the preparation of the budget Repatriation Task Force operations Indonesian Labour Problems and Their Families from Malaysia for the financial year 2008 and 2009; (2) coordinate the formulation Repatriation division of the Indonesian Labour Problems and Their Families from Malaysia between Repatriation Coordination Team Indonesia Labour Problems and Families from Malaysia (TK-PTKIB) established by Presidential Decree No. 106 In 2004 the National Agency for Placement and Protection of Indonesian Workers (BNP2TKI) established through Presidential Regulation No. 81, 2006; (3) report the coordination and recommendations to the Coordinating Minister for People's Welfare and BNP2TKI's head. ${ }^{63}$ In summary, regarding the task of individual departments and institutions, The noticeable trends are as follows. ${ }^{64}$

a. Handling Indonesia Migrant Workers, Indonesia Migrant Workers' candidate and Problematic TKI according to the sense of Law No. 39 of 2004 on PPTKLN, the duty BNP2TKI, in collaboration with relevant sectors and local governments.

b. Handling citizen (TKI, TKIB, and PM (I), PM (I) -BS) in a foreign country into the duty of Ministry of Foreign Affairs through local Indonesia's Embassy in the related country, in cooperation with BNP2TKI, MOSA, relevant sectors and local governments.

\footnotetext{
${ }^{59}$ Wawasan Digital, Nakertrans bentuk Satgas perlindungan TKI on http://www.wawasandigital.com/index.php?option=com_content\&task=view\&id=22826\&Itemid=34, Accessed on May 3, 2019.

${ }^{60}$ Presidential Regulation number 81 of 2006 concerning BNP2TKI

${ }^{61} \mathrm{http}: / /$ www.menkokesra.go.id/pdf/deputi6/tkib_april2008.pdf, Accessed on May 3, 2019.

62 Thttp://kabarnusantara.com/ekonomi-a-bisnis/546-tki-perlu-perlindungan-secara-sistematis, Accessed on May 3, 2019.

${ }^{63}$ Pardjoko Midjan, Pembagian Tugas Penanganan TKI, Loc.Cit.

${ }^{64}$ Ibid.
} 
This formulation is actually correct if we say as an affirmation of the commitment because the tasks have been there on their own. The thing to be noted is the possibility to emerge a tension between the Department of Labour and BNP2TKI related to authority over aspects of the placement of the Law no. 39 of 2004 (hereinafter: Law of Indonesia migrant workers) very "wet" from financial terms.

Other efforts that deserve to get serious attention is the adoption of the act which is currently can be regarded as a basic formulation national protection of migrant workers are also quite controversial. ${ }^{65}$ This Act of Indonesia Migrant Workers has been amended several times, the judicial review by the Constitutional Court either are filed by the sender (sponsor) or their parties ${ }^{66}$. In addition, the members of Parliament also urged for the amendment to the act which deems migrant workers is less clear in services and protection for Indonesia migrant workers. In the other hand, most of the human rights' activists rejected the amendment without ratification CMW and references to it. During this confusion, we need to clarify related to the Indonesia migrant workers' act. The act is intended to be regulations on the placement and protection of migrant workers outside the country. This act also imposes a duty on the state to "provide protection to Indonesia migrant workers during the prior period to departure, the placement period, and the period after placement. ${ }^{67}$ In addition, the act also stipulates the administrative, practical aspects that are comprehensive enough on departure stage of Indonesia migrant workers. ${ }^{68}$ Unlike, the previous issue that is the issue of protection of migrant workers in the act is not done elaborative. The issue of protection is only given by not in deep discussion - not by using terms imperative. ${ }^{69}$

From all the facts above, it shows the actual understanding of protection for workers itself is still unclear. As a result, it is no wonder if, in practice, it happens confusion in it. The only effort that most rational to face standoff is to open opportunities that exist at the international level to get a complete picture on best practices in the management of migration.

\section{Conclusion}

The problem that has always plagued the migrant workers cannot be separated from the chaotic policies and mechanism the protection that plague the domestic Indonesian legal regime for the protection of TKI. It is clear, for example, indicated by the absence of a longterm policy that has coherence and logical. All settlement adopted very ad hoc and unstructured with existing systems. From that one, one of the best ways is to try to ensure labour participation and benefits of globalisation in order to attain the economic development for the nation. Exploiting opportunities outside does not mean our sovereignty diminished but rather as an effort to achieve more substantive effort. This can be interpreted as a political commitment from the government - by learning and cooperating with the globalizing world to be more pragmatic by prioritizing the interests of the people as a form of democracy.

In addition, an important finding that needs to be strengthened is related to issues of cultural relativism ever higher with Asian values. It merely exists in the imagination of the elite. The problems are obstacles that sometimes in the form of rejection in the field of promotion of human rights in Indonesia are more related to lack of Retrieved it. In other words, the issue of ignorance rather than to religious values or culture is more instrumental in the creation of grassroots rejection.

\footnotetext{
${ }^{65}$ http://www.bnp2tki.go.id/content/view/116/163/, Accessed on May 3, 2019.

${ }^{66} \mathrm{http}: / /$ www.mahkamahkonstitusi.go.id/putusan/

putusan_sidang_eng_putusan\%20(019020)\%20PUU\%20III\%202005\%20(UU\%20TKI\%20di\%20luar\%20negeri \%20-\%20English, Accessed on May 3, 2019.

${ }^{67}$ Article 7, Law of Manpower.

${ }^{68}$ Chapter IV, Law of Manpower.

${ }^{69}$ Chapter VI, Law of Manpower.
} 
The legal basis of the Human Rights Act which explicitly recognizes the existence of a right to legal efforts at the international level has been duly made the parties concerned to no doubt take advantage of the international law. In short, the use of international forums on the issue, especially for the Indonesia migrant workers, is one of the main features in the formation of a new national migration management paradigm that is based on human rights. The failure of the state adopt this approach will lead to open up possibilities for international accountability which is requested by the international community and by the citizens of Indonesia.

\section{A. Journal}

\section{References}

Aini, Erika Norliza',, et.al. "ANALISIS PENYELESAIAN SENGKETA PARTAI SOLIDARITAS INDONESIA STUDI PUTUSAN BADAN PENGAWAS PEMILU KOTA BANDAR LAMPUNG NOMOR: 01.PS.REG.BWSL.BDL.08.01.VII.2018.," Cepalo 3, no. 2, 2019: 71-76, DOI: 10.25041/cepalo.v3no2.1846.

Alston, Philip., \& Weiler, J. H. H. “AN 'EVER CLOSER UNION' IN NEED OF A HUMAN RIGHTS POLICY”, European Journal of International Law 9, no. 2, 1998: 658-723, DOI: $10.1093 /$ ejil/9.4.658.

Benvenisti, Eyal. "RECLAIMING DEMOCRACY: STRATEGIC USES OF FOREIGN AND INTERNATIONAL LAW BY NATIONAL COURTS," American Journal of International Law 102, no. 2, 2008: 241-274, DOI: 10.2307/30034538.

Cleveland, Sarah. "LEGAL STATUS AND RIGHTS OF THE UNDOCUMENTED WORKERS," American Journal of International Law 99, no. 2, 2005: 460-465, DOI: $10.2307 / 1562510$.

Gordon, Jennifer. "TRANSNATIONAL NATIONAL LABOR CITIZENSHIP," Southern California Law Review 80, 2007: 503.

Ling, Ceah Whui. "MIGRANT WORKERS AS CITIZENS WITHIN THE ASEAN LANDSCAPE: INTERNATIONAL LAW AND THE SINGAPORE EXPERIMENT." Chinese Journal of International Law 8, no. 1, 2009: 205-231, DOI: 10.1093/chinesejil/jmn041.

Lyon, Beth. "DISCOURSE IN DEVELOPMENT: A POST-COLONIAL 'AGENDA' FOR THE UNITED NATIONS COMMITTEE ON ECONOMIC, SOCIAL, AND CULTURAL COMMITTEE," American University Journal of Gender Social Policy and Law 10, 2003: 535, DOI: 10.2139/ssrn.449301.

Ofreneo, Rene E., \& Samonte, Isabelo A. "EMPOWERING FILIPINO MIGRANT WORKERS: POLICY ISSUES AND CHALLENGES." International Migration Papers no. 62, Jenewa: International Labor Office, 2004.

Pécoud, Antoine., \& deGuchteniere, Paul. "MIGRATION, HUMAN RIGHTS AND THE UNITED NATIONS: AN INVESTIGATION INTO THE OBSTACLES TO THE UN CONVENTION ON MIGRANT WORKERS' RIGHT," Windsor Yearbook of Retrievedto Justice 24, 2006: 241-244.

Simma, Bruno. "UNIVERSALITY OF INTERNATIONAL LAW FROM THE PERSPECTIVE OF PRACTITIONER," European Journal of International Law 20, no. 2, 2009: 265-297, DOI: 10.1093/ejil/chp028.

Stein, Eric. "INTERNATIONAL LAW AND INTERNAL LAW: TOWARD INTERNATIONALISATION OF CENTRAL-EASTERN EUROPEAN CONSTITUTIONS," American Journal of International Law 88, no. 3, 1994: 427-450, DOI: $10.2307 / 2203712$.

\section{B. Book}


Archibugi, D. \& Held, D., eds. Cosmopolitan Democracy. An Agenda For a New World Order. Cambridge: Polity Press, 1995.

Aust, Anthony. Handbook of International Law. New York: Cambridge University Press, 2005.

Bauböck, R. "Citizenship: International, State, Migrant and Democratic Perspectives". In Globalizing Migration Regimes. Avebury: Ashgate, 2006.

Hanson, Gordon H. The Economic Logic of Illegal Immigration. New York: Council on Foreign Relations, 2007.

Donnelly, Jack. Universal Human Rights in Theory and Practice. Ithaca: Cornell University Press, 2003.

Cook, Rebecca. Women's Rights in International Law. Philadelphia: University of Pennsylvania Press, 1994.

Alstons, Philip. Promoting Human Rights through Bill of Rights: Comparative Perspective. New York: Oxford University Press, 1999.

Plender, Richard. Basic Documents on International Migration Law, Leiden and Boston: Martinus Nijhoff, 2007.

\section{Internet}

http://bnp2tki.go.id/ content/view/1394/231/, Accessed on May 3, 2019.

http://www.nakertrans.go.id/news.html,253, Accessed on May 3, 2019.

http://www.cidh.org/annualrep/2002eng/chap.6.htm\#I.\%20\%20\%20\%20\%20\%20\%20\%20IN

TRODUCTION, Accessed on May 3, 2019.

http://www.antara.co.id/view/?i=1199882713\&c=NAS\&s=, Accessed on May 3, 2019.

KOMPAS.com, TKI Tewas Dianiaya Majikan di Arab Saudi, Accessed on May 3, 2019.

http://www.amnestyusa.org/ document.php?id=engasa250072006\&lang=e, Accessed on May 3, 2019.

http://www.menkokesra.go.id/pdf/deputi6/tkib_april2008.pdf, Accessed on May 3, 2019.

http://www.pikiran-rakyat.com/index.php?mib=news.detail\&id=84352, Accessed on May 3, 2019.

http://www.pewglobal.org, Accessed on May 3, 2019.

http://www.pewglobal.org, Accessed on May 3, 2019.

P http://www.tempointeraktif.com/hg/nasional/2006/10/01/brk,20061001-85125,id.html, Accessed on May 3, 2019.

Termsak Chalermpalanupap, "10 Facts about ASEAN Human Rights Cooperation," in http://www.aseansec.org/HLP-OtherDoc-1.pdf, Accessed on May 3, 2019.

http://kabarnusantara.com/ekonomi-a-bisnis/546-tki-perlu-perlindungan-secara-sistematis, Accessed on May 3, 2019.

http://www.majalahtrust.com/ekonomi/ keuangan/981.php, Accessed on May 3, 2019.

http://www.mahkamahkonstitusi.go.id/putusan/putusan_sidang_eng_putusan\%20(019020)\%2

OPUU\%20III 202005\%20(UU\%20TKI\%20di\%20luar\%20negeri)\%20-\%20English, Accessed on May 3, 2019. 